\title{
A spatial analysis of residential land prices in Belgium: accessibility, linguistic border and environmental amenities
}

Florence Goffette-Nagot, Isabelle Reginster, Isabelle Thomas

Décembre 2009

GATE Groupe d'Analyse et de Théorie Économique

UMR 5824 du CNRS

93 chemin des Mouilles - 69130 Écully - France

B.P. $167-69131$ Écully Cedex

Tél. +33 (0)4 72866060 - Fax +33 (0)4 72866090

Messagerie électronique gate@gate.cnrs.fr

Serveur Web : www.gate.cnrs.fr 


\title{
A spatial analysis of residential land prices in Belgium: accessibility, linguistic border and environmental amenities
}

\author{
Florence GOFFETTE-NAGOT ${ }^{1}$ \\ Isabelle REGINSTER $^{2}$ \\ Isabelle THOMAS ${ }^{3}$
}

1 Université de Lyon, Lyon, F-69003, France; CNRS, GATE, UMR 5824, Ecully, F-69130, France. Email: goffette-nagot@gate.cnrs.fr

2 IWEPS Institut Wallon d'Evaluation de Prospective et de Statistique, 5001 Namur, Belgium. Email: ire@iweps.be

3 CORE and FRS-FNRS, Université catholique de Louvain, 1348 Louvain-la-Neuve, Belgium. Email: Isabelle.thomas@uclouvain.be

\begin{abstract}
Aknowledgements: The authors would like to thank the three referees for comments that improved the paper. The funding of this research by a joint grant CNRS / FNRS-CGRI is gratefully aknowledged.
\end{abstract}

\begin{abstract}
This paper explores the spatial variation of land prices in Belgium. The originality of the methodology is threefold: (1) to work at the spatial extent of an entire country, (2) to compute several accessibility measures to all jobs and several representations of the environmental amenities and, more importantly, (3) to test the hypothesis that jobs influence land prices only in the same linguistic region. Spatial autocorrelation is accounted for by estimating spatial models. The results show that the linguistic border acts as a strong barrier in the spatial pattern of land prices and that environmental variables have no significant effect at this scale of spatial analysis.
\end{abstract}

Key words: land price, accessibility, border effect, environment, Belgium JEL codes: R14, R21, R31 


\title{
A spatial analysis of residential land prices in Belgium: accessibility, linguistic border and environmental amenities
}

\begin{abstract}
This paper explores the spatial variation of land prices in Belgium. The originality of the methodology is threefold: (1) to work at the spatial extent of an entire country, (2) to compute several accessibility measures to all jobs and several representations of the environmental amenities and, more importantly, (3) to test the hypothesis that jobs influence land prices only in the same linguistic region. Spatial autocorrelation is accounted for by estimating spatial models. The results show that the linguistic border acts as a strong barrier in the spatial pattern of land prices and that environmental variables have no significant effect at this scale of spatial analysis.
\end{abstract}

Key words: land price, accessibility, border effect, environment, Belgium JEL codes: R14, R21, R31 


\section{Introduction}

Land and housing values vary in space, whatever the spatial scale of analysis. Huge variations can be observed at the scale of a country (e.g., Davis and Palumbo, 2008; Holly et al., 2009). Since Alonso (1964), a large amount of both theoretical and empirical literature has appeared about real estate values and their fall with distance from the central business district (CBD). It has been demonstrated that the land-price gradient is steeper than the housing-price gradient (Fujita, 1989). Of course, this class of models has been subject to many criticisms (notably Hamilton, 1989; see Ma, Banister, 2007 for a recent investigation) but it has also been adapted and tested with success, for instance by incorporating a polycentric form with a number of employment sub-centres, and by considering amenities other than accessibility to the CBD (Anas et al., 1998; Brueckner et al., 1999).

Knowledge of the determinants of land prices has recently been improved by careful analyses of the role of "green" amenities in residential choice modelling, and especially in estimating hedonic prices (e.g., Geoghegan et al., 1997; Tyrvainen and Miettinen, 2000; Irwin and Bockstael, 2001; Kestens et al., 2004; Roe et al., 2004). Theoretical models of urban economics incorporating amenities and open space have also been formulated (e.g., Brueckner et al., 1999; Wu and Plantinga, 2003; Turner 2005), including calibration of structural equations (e.g., Bates and Santerre, 2001; Cheshire and Sheppard, 2002). These models show that it is important to account both for distance to economic opportunities and amenities when analysing the urban equilibrium and residential land prices. As both of these types of determinants are correlated, one could possibly capture the effect of the other if the model omitted one aspect of the model.

Therefore, empirical studies typically regress housing prices against physical distance from the city centre together with a number of control variables, paying attention to structural and 
(more recently) environmental attributes, as well as to spatial methodological pitfalls. These analyses are, however, usually restricted to one urban agglomeration (for recent examples see McMillen and Smith, 2003; Zheng and Kahn, 2008). The analyses that consider a set of agglomerations are often quite general about the spatial pattern of land prices within each agglomeration (Davis and Palumbo, 2007; Holly et al., 2009).

The aim of the present paper is to test a general land-price model incorporating all these factors over an entire country. The estimated model covers different employment centres, the decrease of land prices with distance to employment, and environmental amenities. This model is applied to Belgium. Data availability in Belgium limits the statistical approach to data aggregated at the municipality (commune) level. This limits the type of amenities of which impact can be analysed. Amenities with very local effects such as schools or urban parks can not be taken into account at this scale. Furthermore, dealing with residential land prices only gives information as to the impact of amenities that are valued by the households in their residential location, but this does not allow to measure the recreational value of environmental amenities (see Vermeulen, 2008).

The spatial variation of housing prices in Belgium has recently led to three publications. Vanneste et al (2007) made an impressive exploratory spatial analysis about housing conditions in Belgium, which serves as a useful basis for the understanding of spatial differences in the characteristics of the housing stock; this work however does not provide any multivariate analysis of the spatial variation of land or housing prices. De Bruyne and Van Hove (2006) conducted an econometric analysis of housing prices and not land rents, which is problematic due to the existence of a large amount of unobserved characteristics related to housing quality; furthermore, they account for accessibility to employment located in the two main employment centers for each municipality (Brussels and the province capital) and estimate separate models for Wallonia and Flanders, without considering the interactions 
between the two regions. Recently, Halleux (2009) studied the average plot price in most of the Belgian communes; he highlights the importance of information availability and demand substitutability for explaining housing markets and focuses on gaining insights into how markets are spatially organised (Halleux, 2009, p 2144); this approach however does not account for the effect of accessibility to employment, which is the main determinant of housing and residential land prices in urban economic models.

The present paper improves the existing literature on residential real-estate prices in Belgium by analysing the determinants of residential land prices at a meso-scale level (communes). We focus on the effect of accessibility to employment, taking account of the spatial distribution of all employments. We also consider environmental characteristics and the effect of the linguistic border. The objective is: (1) to explore whether the urban influence is strong enough to explain land prices at the scale of a country; (2) to compare the role of environmental variables and the more traditional effect of transport costs to employment centres; and (3) to measure the effect of the linguistic frontier on land prices. The analysis was conducted at the scale of all 589 communes in Belgium. The methodology relies on three main assumptions: (i) the cumulative effect of the entire urban network on residential land prices can be explored by using measures of accessibility that take into account all the jobs in Belgium and that consider different types of distance-decay functions; (ii) these employment-accessibility measures account for the existence of the linguistic border; and (iii) detailed measures of land use capture the environmental quality at the scale of the commune.

The paper is organised as follows: the modelling approach is developed in Section 2. Section 3 describes the available empirical material (area studied, variables, statistical material). Section 4 gives the results of the empirical analysis and the conclusions are reported in Section 5. 


\section{Empirical approach}

Our method consists of regressing the average residential land prices in each commune on measures of accessibility to employment and environmental characteristics while controlling for a few local variables.

\section{2a. The accessibility of employment}

Belgium is a densely-populated country in which commuting flows are large: $67 \%$ of the economically active population work in a commune other than that where they live (Verhetsel et al., 2007). The small size of the country and the high population density means that several employment centres are often reachable from a given place. Therefore, it is very likely that residential land prices will be influenced by accessibility to several employment centres. Hence, it is useful to consider Belgium as a polycentric area.

Recent urban models have considered several employment centres. Anas et al. (1998) surveyed the theoretical and empirical literature on polycentric cities comprehensively. Literature on employment sub-centres often deals with the identification of sub-centres within a metropolitan area: McMillen (2001) provided both an identification of employment subcentres within the Chicago metropolitan area, and a test of the influence of the distance to these sub-centres on land values. However, rather than considering a finite number of employment centres (that are, in the existing literature, either a priori chosen or endogenously determined, e.g., McMillen, Smith, 2003), the approach followed in this paper consists of accounting for the location of all jobs in Belgium and developing indices of accessibility to employment. This seems to offer a comprehensive view of the influence of employment on land prices and avoids any discussion about concentration versus exurbanisation of jobs, or comments about the specialisation of some communes in some economic activities already discussed elsewhere (e.g., Riguelle et al., 2007 or Vandermotten et al., 2008). Here all jobs in all communes are considered. This choice imposes that the form of the distance-decay 
function and its parameters have to be defined a priori. In order to overcome this shortcoming, several accessibility indices were computed; they differ from each other by the shape of the distance-decay function (Section 3d).

There is unfortunately no consensus about the definition and formulation of the concept of accessibility in the literature (for a recent review see Geurs and Ritsema van Eck, 2001 and DeVries et al., 2009). Handy and Niemeier (1997) suggest that accessibility should be determined by the spatial distribution of potential destinations, the ease of reaching each destination, and the magnitude, quality, and character of the activities found there. Every definition includes one or more components that affect accessibility (e.g., the location of activities, the system of transport). A simple formulation is adopted here, largely inspired by the critical analysis conducted by Vandenbulcke et al. (2007; 2009). Accessibility is measured as a weighted sum of all employment, weights being given by a distance-decay function that allows for the fact that more distant jobs are less accessible. This accessibility is considered as a measure of potential.

In a highly urbanised country, the straight-line distance between two places gives a reasonable idea of their mutual accessibility. The distances between the centroids of the communes as given by a Geographical Information System (GIS) were computed. Pearson product-moment correlations between time-distances (with and without congestion), real distances along the road network and straight-line distances (in kilometres) were computed for a subset of communes; they were always greater than 0.9 (results available from the authors on request; see Vandenbulcke et al. (2007) for more details). The simplest system, the straight-line distance, is used here in order to pay more attention to other sensitive aspects in the modelling process. 
Three forms of the distance-decay function were used: (i) an inverse of the quadratic distance, (a common form of accessibility measure; e.g., Geurs and Ritsema van Eck, 2001); (ii) a negative exponential distance function (a classical functional form for the influence of distance to employment on residential real-estate prices in urban models since Kau and Sirmans, 1979; see Wang, 2009 for a recent example) computed for two different exponents, -0.05 and -0.10 , chosen in conformity with existing studies of land prices that show that estimated land price gradients usually lies between 0.2 and 0.10 (Colwell, Munneke, 1997; McMillen, 2003); and (iii) an inverse of distance with a threshold, according to which employment is only considered within a given radius around each commune; the chosen radii are $40 \mathrm{~km}$ and $50 \mathrm{~km}$, that correspond to acceptable commuting distances in a denselypopulated country like Belgium. These forms are discussed in more detail in Section 3.

The linguistic border is a reality of life in Belgium (see for example Dujardin, 2001 for a review as well as Section 3.a hereunder). This has been considered in previous studies conducted in different but related contexts: Klaassen et al. (1972) measured the psychological distance due to the language difference using telephone traffic, and Gérard et al. (2008) compared the intensity of tax interactions among Belgian municipalities within and between linguistic regions. To account for the fact that residential and employment choices are strongly constrained by linguistic considerations, the accessibility measure is considered separately by region (French-speaking Wallonia, Dutch-speaking Flanders, and bilingual Brussels). Access_intra is the accessibility to jobs located within the same region, while Access_inter is the accessibility to jobs located in another region. Accessibility from Wallonia

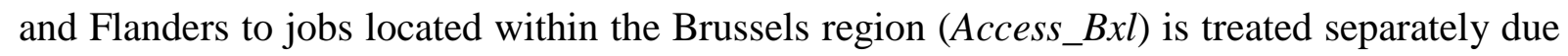
to the uniqueness of Brussels (which is bilingual, centrally located and dominates the Belgian urban landscape, see Thisse and Thomas, 2007 and Section 3a). For communes in the Brussels region, the accessibility to jobs within the Brussels region is the Access_intra 
variable, while Access_Bxl takes the null value. Note that the accessibility values for each commune do not include the commune itself; employment inside the commune is introduced as a separate variable.

\section{2b. Environmental amenities}

Several researchers have already studied the impact of environmental characteristics, be they positive like view on mountains or negative such as noise, on residential land prices (e.g., Germino et al., 2001; Reginster, Goffette-Nagot, 2005; Dekkers, van der Straaten, 2009). Some have considered simply the distance to a given amenity, for instance an urban park, a forested area or open water (e.g., Tyrvainen and Miettinen, 2000; Mahan et al., 2000). More sophisticated methodologies take landscape, such as the view from a given property, into account (e.g., Paterson and Boyle, 2002; Kestens et al., 2004). A lot of attention has also been devoted to the impact of land use and open space in the surroundings of properties (e.g., Irwin, 2002).

As in other recent studies, a GIS technology is used to improve many aspects of the hedonic analysis: various indicators of the greenery of an area were computed and introduced into the regression equations. These indicators combine different sources of data (census data and remotely sensed data), land cover (different types of vegetation), and spatial extent (administrative entities or buffers around a location). In particular, land use was measured for each commune both as the average of the commune grid cells and as a commune-level average over circular windows around each commune cell. The first measure is strictly concerned with land use within the commune, whereas the second reflects the environment as perceived at each location in the commune (see Section 3c). The objective here is to see how far land prices are influenced by ecological characteristics compared to the more traditional economic variables. 


\section{2c. Econometric model}

Land-price equations are estimated on all Belgian communes using three types of explanatory variables: ${ }^{\mathrm{i}}$

$$
\log \left(p_{i}\right)=X_{i} \alpha+Y_{i} \beta+Z_{i} \gamma+u_{i}
$$

where $p_{i}$ is the average unit land price in commune $i, X_{i}$ is a vector of three accessibility variables, $Y_{i}$ is a vector of environmental characteristics, $Z_{i}$ is a vector of control variables and $u_{i}$ is an error term. Because $p_{i}$ is the average of the individual transactions in each commune, the error term is expected to be heteroscedastic and robust variance matrices are estimated using White's correction. There are several reasons why the residuals might be spatially correlated: in particular, unobserved factors that influence land prices are likely to be spatially influenced. Moreover, it is possible that observed land prices in one commune directly influence land prices in the neighbouring communes. For these reasons, the presence of spatial autocorrelation of the residuals was tested (Moran's $I$ ) and two spatial models were estimated: a spatial error model and a spatial lag model.

The spatial error model (SEM) explicitly takes a spatially autoregressive component into account in the error term:

$$
\log (p)=\mathrm{X} \alpha+\mathrm{Y} \beta+\mathrm{Z} \gamma+\varepsilon \text { with } \varepsilon=\lambda W \varepsilon+u
$$

where $\log (p)$ is the $n \times 1$ vector of the logarithms of land prices, $X, Y$ and $Z$ are respectively $n$ $\times 3, n \times j$, and $n \times k$ matrices of observations of the explanatory variables, $W$ is a $n \times n$ spatial weights matrix, $u$ is a $n \times 1$ vector of i.i.d. error terms, $\varepsilon$ is an $n \times 1$ vector of spatially autoregressive error terms and $\lambda$ is the autoregressive parameter to be estimated.

The spatial lag model (LAG) refers to a specification in which land price in a commune $i$ is directly influenced by land prices in neighbouring communes. Formally, in matrix form:

$$
\log (p)=\rho W \log (p)+\mathrm{X} \alpha+\mathrm{Y} \beta+\mathrm{Z} \gamma+\mathrm{u}
$$


with the same notation as above, and where $\rho$ is the spatial autoregressive coefficient to be estimated. The spatial-weights matrix is a simple contiguity matrix defined on the basis of communes having common boundaries. This contiguity matrix is then row standardised so that each row sums to 1 . An ordinary least squares (OLS) estimation allows us to test for the presence of spatial autocorrelation based on a Lagrange multiplier test statistic for error autocorrelation and lag dependence (Anselin, 1988). The spatial error model and spatial lag model are estimated and compared below.

\section{The area and the data}

\section{3a. The area}

Belgium is a small and densely inhabited European country (30,278 sq km and 10 million inhabitants), characterised by a high regional physical diversity and a variety of landscapes. The natural regions are mainly determined by relief, natural conditions and the nature of the soil: from flatland and low land in the North, through the sandy regions of central Flanders, the hilly regions and loamy plateau of Central Belgium, to a high plateau in the South. Belgium is on average highly urbanised but contains considerable regional disparities. The population density in the north and the centre is particularly high and exceeds 500 inhabitants $/ \mathrm{km}^{2}$, while in the southern part, the population density is lower and the people are concentrated in villages and small towns. Even if more than half of the Belgian territory is classified as "urban" and three quarters of the population lives in an urban or suburban commune (Luyten and Van Hecke, 2007), only $20 \%$ of the total surface is covered by buildings or roads. More than half of Belgium is used for agriculture (57\%) (27\% cropland, $18 \%$ grassland and a few permanent crops). Forests and wooded areas cover $20 \%$ of the territory; $80 \%$ of the forests are located in the southern part of the country. 
Belgium is divided into three administrative regions (Flanders, Wallonia and the Brussels Capital Region) (Appendix 1). It is important to note that after federalisation in 1980, town and country planning and environmental planning came under the purview of the regions. Since then the regions have had their own planning policy. The northern part of the country (Flanders) is Dutch speaking while the southern part (Wallonia) is French speaking. In the centre of the country, the Brussels region is officially bi-lingual with a large proportion of French-speaking inhabitants. Belgium is administratively divided into 589 communes (districts, Nuts5 in the Nomenclature of Territorial Units for Statistics used by Eurostat) that are the units of analysis here. One commune (Herstappe) is however so small that most computed indices have abnormal and missing values (esp. for land prices) and hence "pollute" the results. It is withdrawn from all analyses. Hence, the dataset counts 588 communes. Because regional differences may matter, three binary variables (Flanders, Wallonia and Brussels) were introduced to indicate which region each commune belongs to. However, to avoid multicollinearity issues due to correlation between population density and the region dummies, only the Wallonia dummy has been retained in the final specifications. This choice is consistent with the economic proximity of Flanders and Brussels, which are closer to each other than to the Walloon region.

Belgium is dominated by two large urban agglomerations where a large proportion of the economic activities take place: Brussels and Antwerp. Brussels is the main employment centre and attracts people from all over the country (Thisse \& Thomas, 2007). The urban agglomeration of Brussels has more than 1.5 million inhabitants; it is centrally located and sprawls out to across its administrative border into Wallonia and Flanders (Dujardin et al., 2007). Antwerp has half a million inhabitants and is the foremost industrial area and port in the country. In terms of size, Brussels and Antwerp are followed by Ghent $(250,000$ inhabitants), Liège and Charleroi (approximately 200,000 inhabitants each). The urban 
network highly structures the economic poles in terms of job locations (see for example Riguelle et al., 2007). Whatever their size, major and regional Belgian cities are employment centres. City centres have hence a high concentration of jobs, but also contain deprived populations, while the better-off tend to live in the suburbs (see for example Dujardin et al, 2008).

This brief description of the geography of Belgium highlights two important characteristics: (1) Belgium has large regional disparities in landscape, land use and population density; and (2) the city network plays an important role in the location of socio-economic activities and jobs. These characteristics are expected to appear in the following empirical analysis.

\section{3b. Land price data}

Average land prices values are available by commune on the web site of the Belgian National Institute for Statistics (http://statbel.fgov.be/figures/download_fr.asp\#hbs). They refer to all properties sold during a year, and to the price declared to the Public Authority. There may be a difference between declared and real price, but any such bias is here assumed to be independent of location. This paper is limited to developable land (here denoted Land).

The advantage of this database is that it is available for the entire country, using the same methodology, and it appears every year. The statistics cover the total number of plots sold, the average price of one square metre and the average size of a plot sold (Area). A mean value was computed for a three year periods (1999-2001) to avoid very small numbers and to reduce the effects of discrete extreme values; the choice of these three years make it possible to compare the results with the latest census data (2001). Land is hence the average price of a square metre of developable land sold in 1999, 2000 or 2001 in a commune, whatever the size of the plot. As expected, land price is high in communes encompassing a city centre (CBD), and decreases with distance from this commune. This is especially true for Brussels. There is 
also a strong North-South division: land is scarcer in densely populated areas (see Figure 1) (Thomas \& Vanneste, 2007).

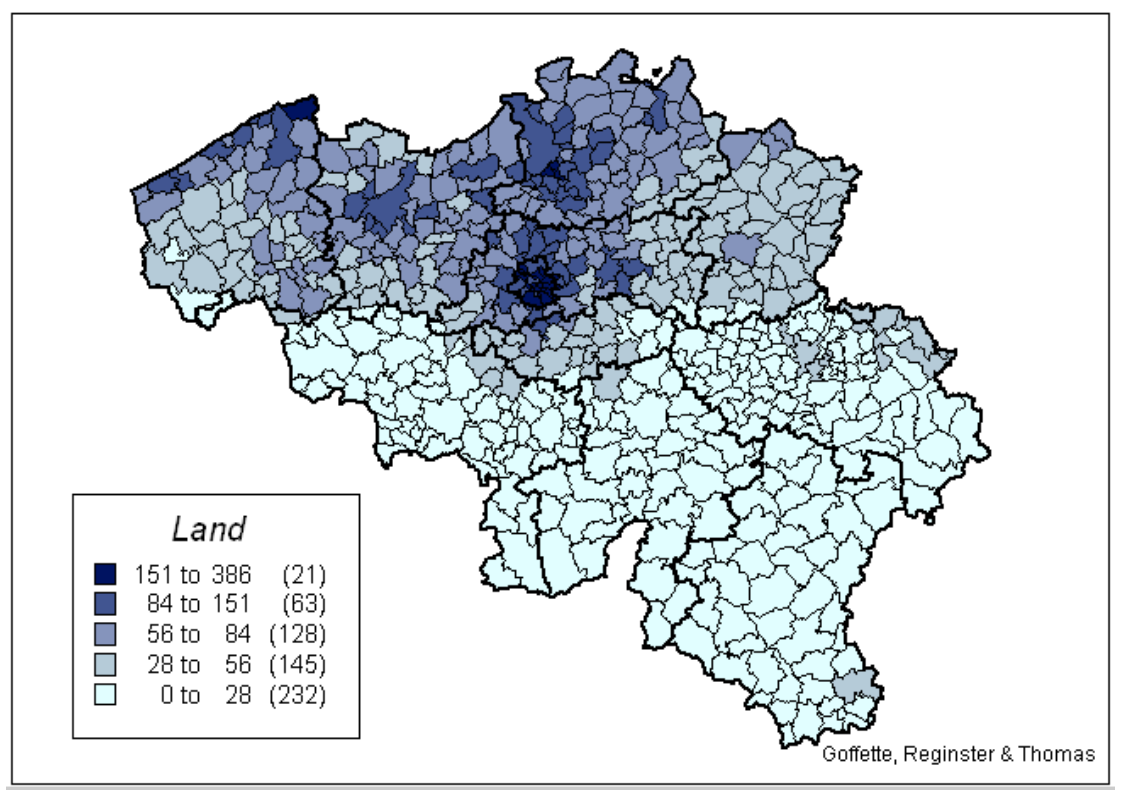

Figure 1: Average price (in €1,000) of one square metre of land in 1999-2001 (Land). Source: Statbel.

\section{3c. Environmental variables}

The CORINE (Coordination of Information on the Environment, European Commission, 2003) land-cover database provides a detailed inventory of the biophysical land cover in Europe using 44 classes. It is made available by the European Environment Agency (EEA) (http://www.eea.eu.int/products) at a resolution of $250 \mathrm{~m}$ grid cells (minimum mapping unit $=$ $25 \mathrm{ha}$ ), and is based on interpretations of remotely sensed photographs taken in the year 2000 . Some of the data in the CORINE database were aggregated to produce synthetic indicators at the commune level. The following variables were constructed:

- the percentage of each commune which is covered in forest (Forest). This corresponds to the aggregation of three of the CORINE classes: broad-leaved forest, coniferous forest, and mixed forest. This percentage is computed as the percentage of the $250 \mathrm{~m}$ square cells in each commune which were entirely covered with forest. 
- the percentage of land devoted to agriculture (Agriculture). This variable is based on the aggregation of the arable land, permanent crop and pasture classes in the CORINE database(class 2). It is computed as the percentage of the $250 \mathrm{~m}$ square cells in each commune devoted to agriculture in 2000 .

Some additional measures of land uses were calculated, taking into account the surroundings of the commune or using different methods of aggregation. The forest environment (Forest_environt) in each commune was calculated. This covers the same classes of forest as Forest, but the aggregation method is different: it is the mean percentage of forest cells, inside a circular window of radius $20 \mathrm{~km}$ around each $250 \mathrm{~m}$ grid cell in the commune. It represents the situation in 1990. Figures 2 and 3 compare the spatial distribution of the Forest and Forest_environt variable. An Agriculture_environt variable was defined for agricultural land use in a similar way.

The North Sea coast (which is quite touristy and urbanised) was expected to generate higher land prices. Two coastal variables were computed: Coast indicates the presence (1) or absence (0) of the coast as a border of the commune. Coastprox takes the value 1 in communes not actually on the seafront but located less than $20 \mathrm{~km}$ from it, and 0 otherwise. The presence of water (a lake or river) in a commune is also expected to be an attractive amenity. Water takes the value 1 when there is such an amenity in the commune and 0 when it is absent. Finally, Slope is the average gradient of road segments in each commune (Data source: Vandenbulcke et al, 2007). It is used as a proxy for landscape, on the assumption that hilly landscapes are more attractive to residents. 


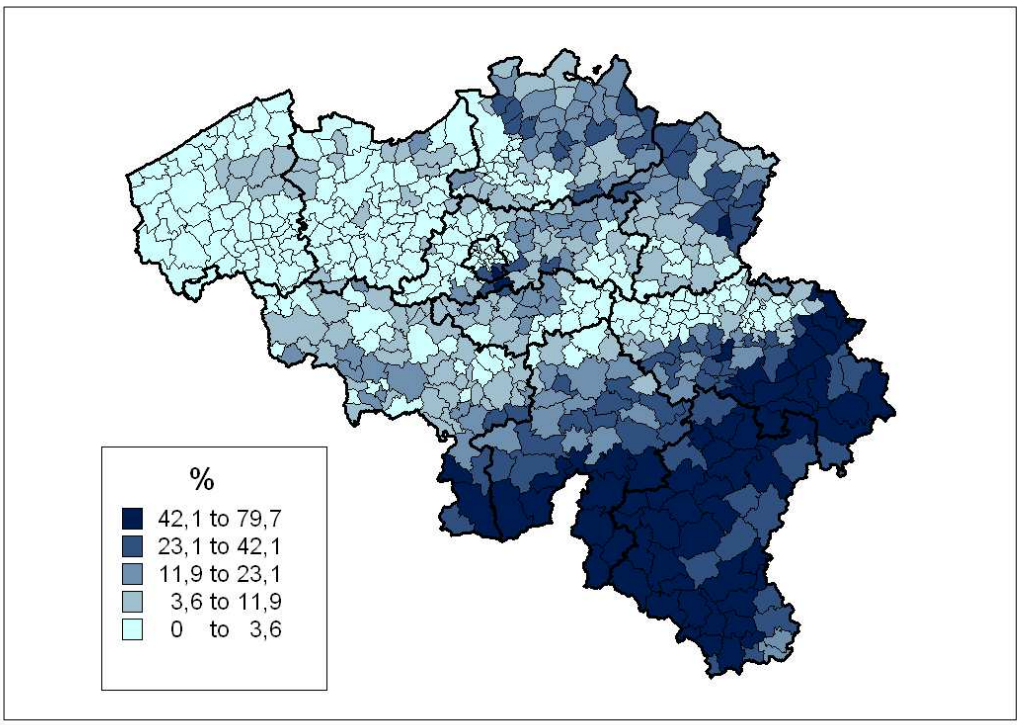

Figure 2: Percentage of $250 \mathrm{~m}$ square cells in each commune that are covered with forest (noted Forest).

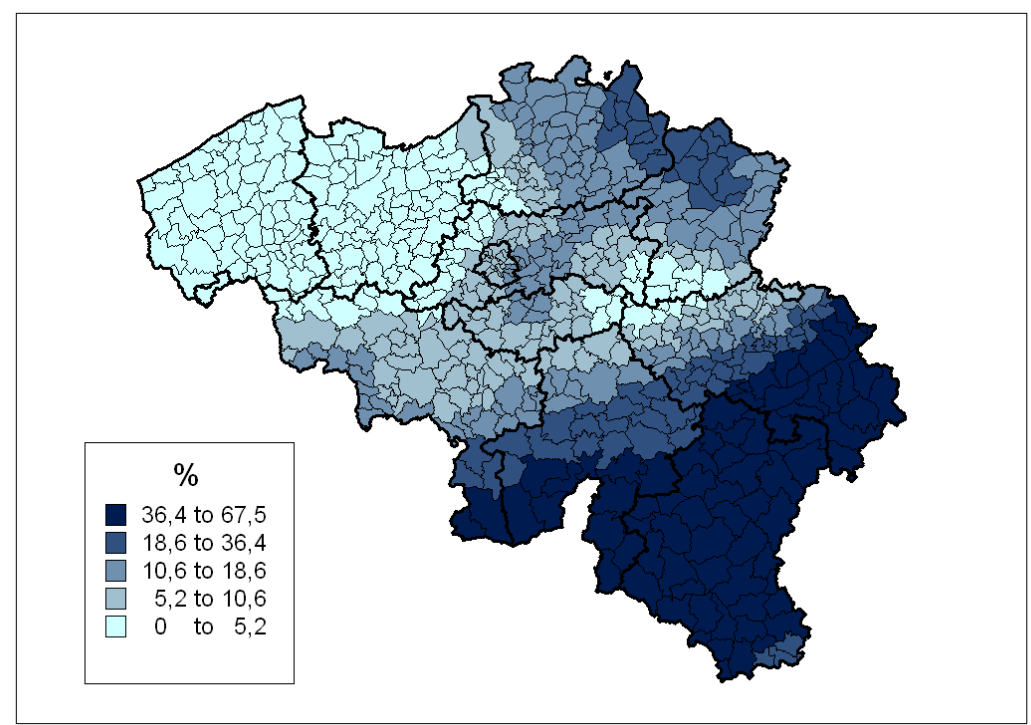

Figure 3: Average percentage of forested cells, inside a circular window of radius $20 \mathrm{~km}$ around each $250 \mathrm{~m}$ grid cell in the commune (noted Forest_environt). 


\section{3d. The accessibility of employment}

In line with the regional split in Belgium, the accessibility of employment for a commune $i$ is considered to have three components:

(1) Access_intra $a_{i}=\sum_{j \in R_{i}, j \neq i} f\left(d_{i j}\right) j o b_{j}$ is the sum of all the jobs located in the same region as $i$, weighted by a distance-decay function $f\left(d_{i j}\right)$, where $d_{i j}$, is the straight-line distance between the centroids of communes $i$ and $j$ and $j o b_{j}$ is the number of jobs in commune $j$.

(2) Access_inter $r_{\mathrm{i}}=\sum_{j \notin R_{i}} f\left(d_{i j}\right) j o b_{j}$ is the sum of all the jobs located in the other region (Flanders for Wallonia and Wallonia for Flanders and Wallonia and Flanders for Brussels), weighted by a distance-decay function $f\left(d_{i j}\right)$.

(3) Access_bxl $l_{\mathrm{i}}=\sum_{j \in R_{B}} f\left(d_{i j}\right) j o b_{j}$ is the sum of all jobs located in the Brussels region (denoted $R_{B}$ ), weighted by a distance-decay function $f\left(d_{i j}\right)$. Note that accessibility of jobs in Brussels for the Brussels communes is measured in variable Access_intra.

Due to the linguistic border, it is expected that the accessibility of employment located in the other linguistic region will have less influence on land prices than employment located in the same region: it is as if the employment in the other linguistic region was further away, or as if the frontier between the two regions had some thickness. This applies to Flanders and Wallonia seen as two "linguistic regions" but not for Brussels that is bi-lingual and that attracts a lot of commuters whatever their place of residence; this is why the Acces_bxl variable is also considered.

This approach forces us to choose the functional form for the distance-decay function and its parameter. Three types of distance-decay functions were computed: inverse of negative powers of distance with parameters -1 and -2 , negative exponential functions with parameters -0.10 and -0.05 and inverse distance functions with two different thresholds, as follows: 


$$
\begin{aligned}
& f\left(d_{i j}\right)=d_{i j}^{-2} \\
& f\left(d_{i j}\right)=\exp \left(-0.05 d_{i j}\right) \\
& f\left(d_{i j}\right)=\exp \left(-0.10 d_{i j}\right) \\
& f\left(d_{i j}\right)=d_{i j}^{-1} \text { if and only if } d_{i j} \leq 40 \mathrm{~km} \\
& f\left(d_{i j}\right)=d_{i j}^{-1} \text { if and only if } d_{i j} \leq 50 \mathrm{~km}
\end{aligned}
$$

However, preliminary multicollinearity tests revealed high variance inflation factors in the model using the inverse quadratic function of distance 4.1. As a result, only the functions 4.2 to 4.5 were retained and are used in the following. They will be introduced into the price equations in turn, and the fits of the regression equations will be compared.

Figure 4 illustrates the effect of these choices on the accessibility measures: the accessibility of jobs located in the same linguistic region (Access_intra), in the other linguistic region (Access_inter), and in the Brussels region (Access_Bxl), when the distance-decay function is either the negative exponential of -0.10 (Equation 4.3), or the inverse of the distance with a $40 \mathrm{~km}$ threshold (Equation 4.4). Access_intra is lower in Wallonia than in the two other regions. Access_inter is high of course near the linguistic border but also in Brussels, as the communes in the Brussels region have access both to jobs in Wallonia and in Flanders.

\section{3e. Socio-economic variables}

Jobs is the number of jobs in each commune. This variable is obtained from the housing and population census (2001), where each inhabitant had to declare his or her place of work and place of residence. It is used in computing the accessibility variables, and to measure the effect of jobs in the commune itself. 


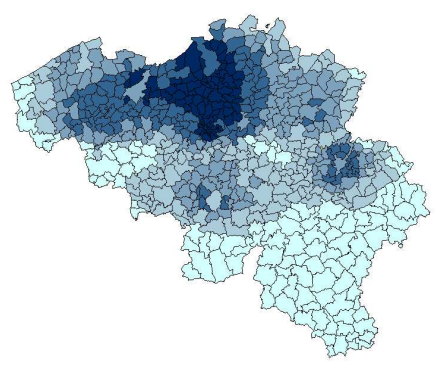

$\boldsymbol{a}$ Access_intra and [4.3]

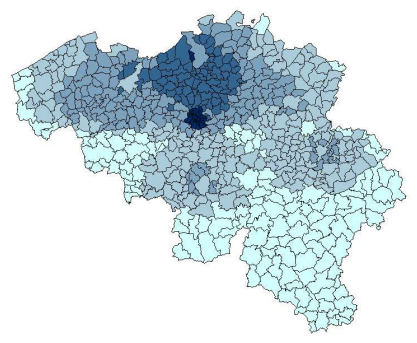

$\boldsymbol{d}$ Access_intra and [4.4]

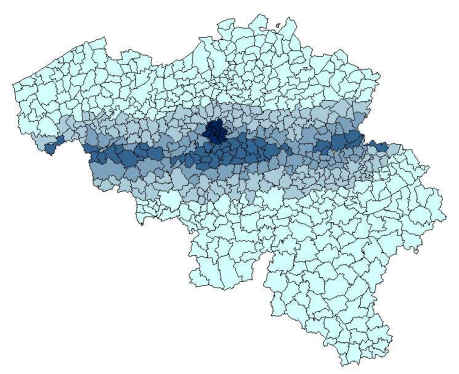

b Access_inter and [4.3]

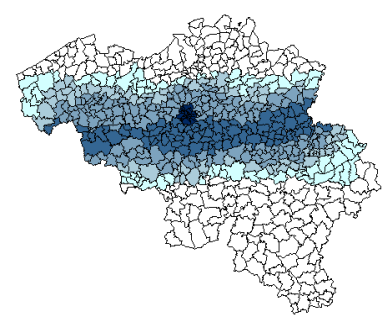

$\boldsymbol{e}$ Access_inter and [4.4]

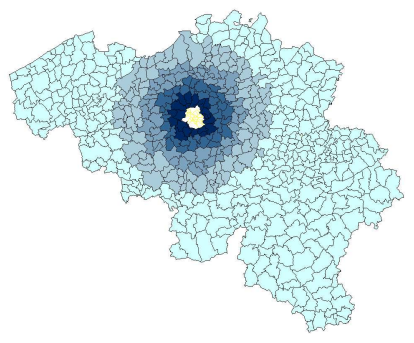

c Access_bxl and [4.3]

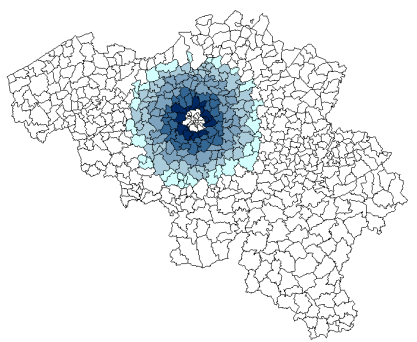

f Access_bxl and [4.4]

Figure 4: The accessibility spatial structures for different distance-decay functions and border effects (legend has been removed to improve legibility)

Popdens states the population density and hence accounts for the urban effect. It is simply expressed as the total number of inhabitants in a commune divided by its total area, and measures the pressure on land: high densities reinforce competition for land, and is synonymous of high land prices and scarcity of available land plots .

Income is a measure of regional wealth, based on the median declared income in each commune. The data are officially available each year from http://www.statbel.fgov.be/ home_fr.asp. This variable is aimed at accounting for the impact of local wealth on land prices: available income increases the willingness to pay for desirable characteristics in the commune. However, it is also known that high-income households are likely to sort themselves into communes with high land prices (this bi-variate relationship has already been 
discussed for Belgium by Thomas and Vanneste, 2007). There is therefore a potential endogeneity problem. This is avoided here by taking the average value of households' income over the labour-market area (labour-market areas are delineated for the 22 largest cities in the country).

Tables 1 and 2 summarise the main descriptive statistics and the significant spatial autocorrelations for all the variables used in this study. Diagnostics of multicollinearity were performed and all the results presented here are for estimations in which the highest variance inflation factor is below 10 (results available on request).

\section{Insert Tables 1 and 2 about here}

\section{Results}

\section{4a. Comparing spatial models}

Estimations were performed with the OLS method (OLS), the spatial error model (SEM) and the spatial lag model (LAG). Table 3 gives the OLS, SEM and LAG estimated coefficients and their standard errors, in each case for two different specifications of the distance-decay function. The Lagrange multiplier test for the two spatial models revealed the presence of spatial autocorrelation, which has to be accounted for to avoid biased or inefficient estimates. The choice of a spatial model is based on a comparison of likelihoods (Anselin, 1988). Table 3 shows that, whatever the specification of the accessibility function, the LAG model had the highest likelihood, meaning that the data exhibits a spatial pattern in which land prices are influenced by land prices of neighbouring communes instead of by unobserved characteristics in those communes.

Table 3 shows that the estimates of the SEM model are similar to the OLS estimates. Moran's I for the residuals of these regressions (bottom lines of Table 3), show that the SEM model 
has a similar spatial structure of residuals to the OLS. On the contrary, the residuals of the LAG model have a very different structure, with a low negative value of the Moran's I, especially in the exponential specification. This results of course from the underlying spatial structure of the LAG model, in which the influence of land prices in neighbouring communes is specifically taken into account, and therefore taken out of the residuals.

\section{Insert Table 3 about here}

Figure 5 compares the OLS and LAG residuals. Whereas the spatial pattern of the OLS residuals is visible, there is no clear spatial pattern for the LAG residuals, although the Moran's I shows a low negative spatial association.

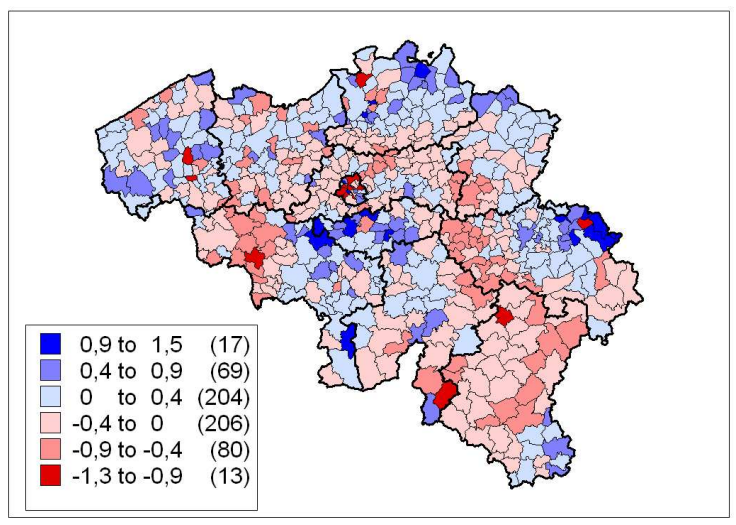

a: OLS residuals

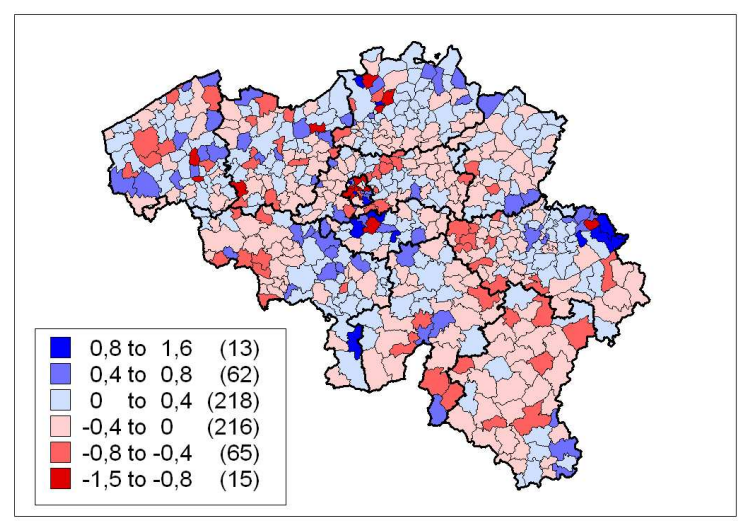

b: LAG residuals

Figure 5: Maps of residuals

When comparing the coefficients for all three models, it is clear that several coefficients (Coast, Coastprox, Slope and Wallonia) are smaller in the SEM than the OLS model, and are lower by a factor of two or more in the LAG estimates. This means that ignoring the spillovers of land prices (as occurs in the OLS and SEM models) in neighbouring communes can falsely increase the effects of exogenous variables. Indeed, we know that OLS coefficients are biased when when some spatial autocorrelation of the explained variable is present in the data. The same applies to the accessibility to Brussels (Access_Bxl) and to the 
intra-regional accessibility (Access_intra). The level of employment in the commune (Jobs) is no longer significant in the LAG model.

Two variables (Forest, Agriculture) have an unexpected negative sign in the OLS estimation with inverse distance with a $40 \mathrm{~km}$ threshold; in the spatial models (SEM and LAG) they are not significant. This once again means that ignoring the low level of land pressure in neighbouring communes in the OLS regression gives misleading results. These results are in line with those obtained by Möller (2007), in testing a model for residential prices in Germany.

Given the results of this comparison of spatial models, the following discussion will be limited to the spatial LAG model.

\section{4b. Comparing accessibility indices: the distance-decay effect}

Regressions were performed to test the stability of the models with respect to the form of the accessibility measure (i.e., the distance-decay effect) and to enhance our understanding of its influence. Table 4 gives the results for the LAG regressions for the four distance-decay functions: two negative exponentials (exponents -0.05 and -0.10 ) and two inverse distance functions (thresholds 40 and $50 \mathrm{~km}$ ).

\section{Insert Table 4 about here}

The coefficients for intra-regional accessibility (Access_intra) associated with the inverse distance functions are not significant. However, accessibility to Brussels (Access_Bxl) always has a positive significant effect in the regressions, and this effect is larger in the inverse distance specifications than in the exponential specifications (Columns 3 and 4 compared to Columns 1 and 2). The interpretation is twofold. First, the effect of Brussels is so important 
that it is not sensitive to the way in which the distance-decay is expressed. Second, Access_bxl with the inverse distance-decay functions exhibits a strong spatial differentiation, due to the shrink of the variable beyond the threshold around Brussels (see Figure $4 \mathrm{f}$ ). This corresponds well to the pattern of land prices around Brussels. The spatial differentiation of Acces_intra with this distance-decay function is much lower (Figure 4d). Consequently, this outweighs the effect of intraregional accessibility. Moreover, the residuals exhibit substantial remaining autocorrelation after the estimation of the LAG model with the inverse distance specification of accessibility, but this is lower in the exponential specification (bottom lines of Table 4). A possible interpretation is that the inverse distance function with a threshold understates job accessibility beyond the threshold. This causes higher residuals beyond the threshold, and these residuals are obviously spatially correlated.

This gives an indication of the form of the accessibility index that best suits the spatial differentiation of land prices in Belgium. The negative exponential function best captures the influence of the spatial distribution of employment on land prices at the scale of the country. Unsurprisingly, this is the classical functional form used in urban monocentric models.

\section{4c. Environment versus accessibility}

As expected, land prices were positively influenced by the presence of the coast (Coast) and by being within $20 \mathrm{~km}$ of the coast (Coastprox) (see Table 4). The coefficient of Slope was negative, indicating that hilly areas tend to have low land prices. This may be explained by the fact that steep slopes (such as those in the Ardennes hills) are associated with very low demand for land. Another interpretation is that the straight-line distance considered in our accessibility measures is likely to yield an overestimation of the real level of accessibility in 
the eastern part of the country. This effect would be captured by the Slope variable, resulting in the observed negative coefficient.

Unexpectedly, the three other environmental variables (Water, Forest and Agriculture) did not influence land prices significantly and their environmental variants (Forest_environt and Agricult_environt) were not significant in any of the models (not shown). At this scale of analysis, the effect of landscape on land prices is not evident; it is probably more significant at an intra-communal level (see for example Kestens et al., 2004).

Variables that measure the proximity of a commune to economic opportunities had clear effects. Accessibility to jobs in the same region (Access_intra) influenced land prices positively, although jobs in the other region had no significant influence (Access_inter): thus proximity to jobs in Flanders did not affect land prices in Wallonia, and vice versa. This result indicates that the two regions function independently in terms of labour market areas. Regions are isolated from each other due to their linguistic differences. The effect of accessibility to Brussels is a different story: as the principal city, it attracts commuters from far away in the country (Verhetsel et al., 2007).

Accessibility to jobs seems to be more important to households than jobs in the commune itself, which did not impact land values in the LAG model. This is not surprising given the intensity of commuting at this level. Similarly, population density in the commune had only a slightly significant effect. More importantly, the average household income in the labour market area (Income) had a very significant effect whatever the estimated model. Wealth supplements proximity to job opportunities in explaining spatial differentials in land prices.

Finally, the regional variable for Wallonia has a negative coefficient. This dummy variable is likely to capture unmeasured variables, such as specific planning or housing policies; the differences between regions are driven by political choices but also by the specific history and 
geography of the regions. In Wallonia, for instance, there is a longer tradition in renovation support even if recently the difference with Flanders is shrinking (Vanneste et al., 2007).

To assess the relative importance of the various factors affecting land prices, it is possible to calculate the effects of the continuous variables as the changes in the land price in standard deviation that are produced by a one standard deviation change in each of the variables. Table 5 shows these effects for the variables that are significant in the LAG model estimated with the exponential form of the accessibility measure (exponent -0.10 ). Although the coefficient of population density was not very significant, a change of one standard deviation in the population density of the commune changed land prices by almost one standard deviation. The effect of accessibility to jobs in the region and of being on the coast were slightly weaker but of the same order of magnitude. The impacts of accessibility to jobs in Brussels, of average income in the commune, and of average hilliness, were about half a standard deviation.

\section{Insert Table 5 about here}

In summary, at the level of the 588 communes in Belgium, the traditional determinants of land prices (that is accessibility to jobs and population density), had more influence on the spatial distribution of residential land prices than the environmental variables. The four landuse variables considered in these estimations had no effect on land values.

\section{Conclusion}

The objective of this paper was to identify the importance of environmental variables for explaining urban land prices within one country, and more particularly to compare their role to those of more classical variables. The accessibility of jobs was studied in detail. Spatial 
models were estimated to account for the spatial autocorrelation that is common in hedonic analyses of land prices. A major result is that, at the level of the whole country, variations in land prices mainly result from the role of distance (a factor that depends on the unit transport cost and the trade off between transport and land costs); natural amenities do not have a stable or well-defined role. Environmental and natural variables are probably more important at a local level. We also observe that the border between Wallonia and Flanders acts as a barrier between the labor-markets of the two regions, as revealed by the effect of accessibility of employment on land prices. This result confirms those of Dujardin (2001) on commuting flows.

The effect of the linguistic border is distinct from the observation that land rents differ, ceteris paribus, depending on the region, as measured by the effect of the binary variable that contrasts Wallonia to Flanders. Indeed, our results suggest that the structure of land prices depends on the geography of the country, taken as a whole, but also upon the land-use policy: land-use planning policy in Belgium is different in the North and the South, Wallonia having more space than Flanders, lower population density, a weaker economy, different historical traditions, and a long tradition of housing renovation (by taste or supported by public policy). Hence, geography, history, economy, linguistic border and land-use policy interact to explain the spatial structure of land prices. 


\section{References}

Alonso W (1964), Location and Land Use Harvard University Press, Cambridge

Anas A, Arnott R and Small KA (1998), Urban spatial structure, Journal of Economic Literature, 36 : $1426-1464$

Anselin L (1988), Spatial Econometrics: Methods and Models In Studies in Operational Regional Science Boston: Kluwer Academic Publishers

Bates LJ and Santerre RE (2001), The public demand for open space: the case of Connecticut communities, Journal of Urban Economics, 50: 97-111

Brueckner JK, Thisse JF and Zenou Y (1999), Why is central Paris rich and downtown Detroit poor? An amenity-based Theory, European Economic Review, 43: 91-107

Cheshire P and Sheppard S (2002), The welfare economics of land use planning, Journal of Urban Economics, 52: 242-269

Colwell PF and Munneke HJ (1997), The Structure of Urban Land Prices, Journal of Urban Economics, 41: $321-336$

Davis MA and Palumbo MG (2008), The price of residential land in large US cities, Journal of Urban Economics, 63: 352-384

De Bruyne K and Van Hove J (2006), Explaining the Spatial Variation in Housing Prices: An Economic Geography Approach, Center for Economic Studies Discussion papers, KULeuven

Dekkers JEC and van der Straaten JW (2009), Monetary valuation of aircraft noise; a hedonic analysis around Amsterdam airport, Ecological Economics, 68: 2850-2858

De Vries JJ, Nijkamp P and Rietveld P (2009), Exponential or power distance-decay for commuting? An alternative specification, Environment and Planning A, 41: 461-480

Dujardin C (2001), Effet de frontière et interaction spatiale Les migrations alternantes et la frontière linguistique en Belgique, L'Espace Géographique, 30: 307-320 
Dujardin C, Selod H and Thomas I (2008), Residential segregation and unemployment: the case of Brussels, Urban Studies 45: 89-113

Dujardin C, Thomas I and Tulkens H (2007), Quelles frontières pour Bruxelles? Une mise à jour Reflets et Perpectives de la Vie Economique, XLVI:2-3, pp 155-176

European Commission (2003), CORINE Land Cover Map and Technical Guide European Union Directorate-General Environment, Nuclear Safety and Civil Protection, Luxembourg Fujita M (1989), Urban Economic Theory, Cambridge: Cambridge University Press.

Geoghegan J, Wainger LA and Bockstael NE (1997), Spatial landscape indices in a hedonic framework: an ecological economics analysis using GIS, Ecological Economics, 23: 251-264

Germino M J, Reiners WA, Blasko B J, McLeod D and Bastian C T (2001), Estimating visual properties of Rocky Mountain landscapes using GIS, Landscape and Urban Planning, 53: 71-83

Gérard M, Jayet H and Paty S (2008), Tax Interactions Among Belgian Municipalities: Does Language Matter?, Journées Louis André Gérard-Varet No 7, Marseille, 17-18 June

Geurs KT and Ritsema van Eck JR (2001), Accessibility Measures: Review and Applications RIVM Report 408505 006, National Institute of Public Health and the Environment, Bilthoven (<wwwrivmnl/bibliotheek/rapporten/408505006html>)

Halleux J-M (2009), The spatial structuring of inter-urban housing markets: application to building sites prepared for self-provided housing, Environment and Planning A, 41: 2143-2161

Hamilton BW (1989), Wasteful Commuting again, Journal of Political Economy, 97: 1497-1504.

Handy SL and Niemeier DA (1997), Measuring accessibility: an exploration of issues and alternatives Environment and Planning A, 29: 1175-1194

Holly S, Pesaran MH and Yamagata T (2009), A spatio-temporal model of house prices in the US, IZA Discussion Paper No. 2338.

Irwin EG (2002), The effects of open space on residential property values, Land Economics, 78: 465480 
Irwin EG and Bockstael NE (2001), The problem of identifying land use spillovers: measuring the effects of open space on residential property values American Journal of Agricultural Economics, 83: 698-704

Kau JB and Sirmans CF (1979), Urban land value functions and the price elasticity of demand for housing, Journal of Urban Economics, 6: 112-121.

Kestens Y, Thériault M and Des Rosiers F (2004), The impact of surrounding land use and vegetation on single-family house prices Environment and Planning B, 31: 539-567

Klaassen L, Wagenaar S and Van der Weg A (1972), Measuring psychological distance between the Flemings and the Walloons, Papers of the Regional Science Association, 29: 45-62

Luyten S and Van Hecke E. (2007), De Belgische Stadsgewesten (the Belgian urban areas), Working Paper, INS-Statbel http://193.191.210.44/pub/d0/p009n014_nl.pdf

Ma K-R and Banister D (2007), Urban spatial change and excess commuting, Environment and Planning A, 39: 630-646.

Mahan BL, Polasky S and Adams RM (2000), Valuing urban wetlands: a property price approach, Land Economics, 76: 100-113

McMillen D P (2001), Nonparametric employment subcenter identification Journal of Urban Economics, 50: 448-473

McMillen DP (2003), The return of centralization to Chicago: using repeat sales to identify changes in house price distance gradients, Regional Science and Urban Economics, 33:287-304

McMillen D and Smith S (2003), The number of sub-centres in large urban areas Journal of Urban Economics, 53: 321-338

Möller J (2008), Regional variations in the price of building land: a spatial econometrics approach for West Germany, Annals of Regional Science, Special issue paper DOI 101007/s00168-007-0207-6 Paterson RW and Boyle KJ (2002), Out of sight, out of mind? Using GIS to incorporate visibility in hedonic property value models, Land Economics, 78: 417-425 
Reginster I and Goffette-Nagot F (2005), Urban environmental quality in two Belgian cities, evaluated on the basis of residential choices and GIS data, Environment and Planning A, 37: 1067-1090.

Riguelle F, Thomas I and Verhetsel A (2007), Is the Belgian city polycentric? A geographical approach, Journal of Economic Geography, 7: 193-215

Roe B, Irwin EG and Morrow-Jones HA (2004), The effects of farmland, farmland preservation, and other neighbourhood amenities on housing values and residential growth, Land Economics 80: 55-75

Thisse J-F and Thomas I (2007), Bruxelles et Wallonie : une lecture de la vie économique urbaine, Reflets et Perspectives de la Vie Economique, XLVI(1): 75-93

Thomas I and Vanneste D (2007), Le prix de l'immobilier en Belgique : Un peu de géographie ! Les Echos du Logement, 1: 17-25

Turner MA (2005), Landscape preferences and patterns of residential development, Journal of Urban Economics, 57: 19-54

Tyrvainen L and Miettinen A (2000), Property prices and urban forest amenities, Journal of Environmental Economics and Management, 39: 205-23

Vandenbulcke G, Steenberghen $\mathrm{T}$ and Thomas I (2007), Accessibility Indicators to Places and Transport, Politique Scientifique Fédérale et SPF Mobilité et Transports, Brussels (http://wwwmobilitfgovbe/data/mobil/accessibilityfepdf)

Vandenbulcke G, Steenberghen T and Thomas I (2009), Mapping accessibility in Belgium: a tool for land-use and transport planning? Journal of Transport Geography, 17: 39-59

Vanneste D, Thomas I and Goossens L (2007), Le Logement en Belgique Bruxelles, SPF-Economie, PME, Classes moyennes et énergie, pp 211

Vandermotten C, Halbert L, Roelandts M and Cornut P (2008), European Planning and the Polycentric Consensus : Wishful Thinking ?, Regional Studies, 42: 1205-17. 
Verhetsel A, Thomas, I, Van Hecke E and Beelen, M (2007), Pendel in België Deel I: de woonwerkverplaatsingen; in Statistics Belgium Algemene Directie Statistiek en Economische Informatie (Former NIS), Brussel, No 15, pp166, http://wwwstatbelfgovbe/pub/d0/p009n015 nlpdf Vermeulen W (2008), Essays on housing supply, land use regulation and regional labour markets, $\mathrm{PhD}$ Thesis, Vrije Universiteit Amsterdam http://www.cpb.nl/nl/org/homepages/wvm/Thesis.pdf Wang R (2009), The Structure of Chinese Urban Land Prices: Estimates from Benchmark Land Price Data, Journal of Real Estate Finance and Economics, 39: 24-38

Wu JJ and Plantinga AJ (2003), The influence of public open space on urban spatial structure, Journal of Environmental Economics and Management, 46: 288-309

Zheng S and Kahn ME (2008), Land and residential property markets in a booming economy: new evidence from Beijing, Journal of Urban Economics, 63: 743-757 
Appendix 1

Studied area

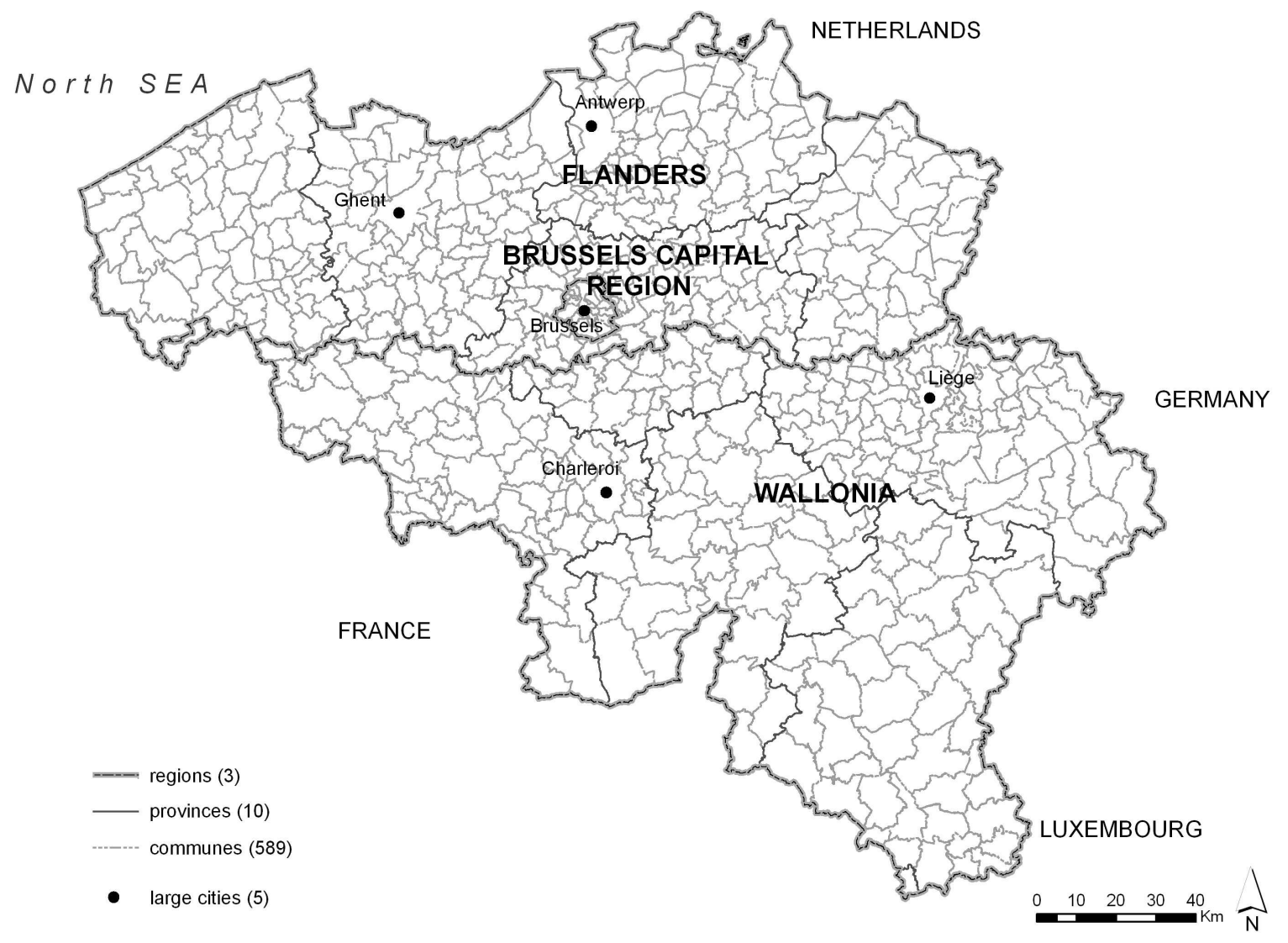




\begin{tabular}{|c|c|c|c|c|c|c|}
\hline Description & Name & Units & Mean & St. dev. & Minimum & Maximum \\
\hline Land price & Land & $\times 1000 €$ & .0649 & .1520 & .00371 & 2.8954 \\
\hline \multicolumn{7}{|l|}{ Accessibility indices } \\
\hline \multicolumn{7}{|l|}{$\operatorname{Exp}(-0.05$ distance $)$} \\
\hline Intra-regional & Intra_exp05 & & 150.86 & 93.42 & 9.30 & 416.46 \\
\hline Inter-regional & Inter_exp05 & & 42.41 & 57.40 & 0.19 & 317.41 \\
\hline Brussels & Bxl_exp05 & & 48.63 & 68.49 & 0 & 349.33 \\
\hline \multicolumn{7}{|l|}{$\operatorname{Exp}(0.10$ distance $)$} \\
\hline Intra-regional & Intra_exp05 & & 54.97 & 53.47 & 2.01 & 361.21 \\
\hline Inter-regional & Inter_exp05 & & 8.10 & 17.70 & 0.00007 & 108.78 \\
\hline Brussels & Bxl_exp05 & & 14.46 & 36.40 & 0 & 249.54 \\
\hline \multicolumn{7}{|l|}{$1 /$ distance $(<40 \mathrm{~km})$} \\
\hline Intra-regional & Intra_inv40 & & 20.79 & 21.95 & 0.74 & 230.8 \\
\hline Inter-regional & Inter_inv40 & & 3.12 & 6.37 & 0 & 38.67 \\
\hline Brussels & Bxl_inv40 & & 5.51 & 11.70 & 0 & 78.83 \\
\hline \multicolumn{7}{|l|}{$1 /$ distance $(<50 \mathrm{~km})$} \\
\hline Intra-regional & Intra_inv50 & & 23.63 & 22.30 & 1.00 & 230.8 \\
\hline Inter-regional & Inter_inv50 & & 4.58 & 8.25 & 0 & 48.89 \\
\hline Brussels & Bxl_inv50 & & 6.64 & 11.68 & 0 & 78.83 \\
\hline Jobs in the commune & Jobs & $\times 1000$ & 5.012 & 14.414 & 0.066 & 203.186 \\
\hline $\begin{array}{l}\text { Commune } \\
\text { population density }\end{array}$ & Popdens & $\begin{array}{l}\times 1000 \\
\text { pop/sq km }\end{array}$ & 686 & 1782 & 22 & 20258 \\
\hline $\begin{array}{l}\text { Average income in } \\
\text { labour market area }\end{array}$ & Income & $\times 1000 €$ & 19.432 & 1.133 & 16.819 & 21.313 \\
\hline Brussels' region & Brussels & - & 0.032 & 0.177 & 0 & 1 \\
\hline Flanders region & Flanders & - & 0.522 & 0.500 & 0 & 1 \\
\hline Wallonia region & Wallonia & - & 0.446 & 0.497 & 0 & 1 \\
\hline Coastal commune & Coast & - & 0.170 & 0.129 & 0 & 1 \\
\hline $\begin{array}{l}\text { Commune }<20 \mathrm{~km} \\
\text { coast (not on coast) }\end{array}$ & Coastprox & - & 0.010 & 0.101 & 0 & 1 \\
\hline Average slope & Slope & $\circ$ & 2.810 & 1.968 & 0.685 & 10.842 \\
\hline Presence of water & Water & - & 0.570 & 0.496 & 0 & 1 \\
\hline $\begin{array}{l}\text { Land covered by } \\
\text { agriculture }\end{array}$ & Agriculture & $\%$ & 58.036 & 21.395 & 0 & 98.715 \\
\hline $\begin{array}{l}\text { Land covered by } \\
\text { forest }\end{array}$ & Forest & $\%$ & 13.702 & 17.538 & 0 & 79.617 \\
\hline
\end{tabular}

Table 1: Descriptive statistics $(n=588)$ 


\begin{tabular}{|l|c|c|}
\hline Variable & Moran's I & $\boldsymbol{z}$ stat. \\
\hline Land price & $0.178 * * *$ & 8.990 \\
\hline Jobs & $0.010 \mathrm{n} . \mathrm{s}$. & 0.523 \\
\hline Popdens & $0.474 * * *$ & 19.863 \\
\hline Agriculture & $0.099 * * *$ & 3.989 \\
\hline Forest & $0.107 * * *$ & 4.312 \\
\hline
\end{tabular}

n.s. not significant; $* \mathrm{p}<0.1 ; * * \mathrm{p}<0.05 ; * * * \mathrm{p}<0.01$

Table 2: Global autocorrelation analysis for the main dependent and independent variables 


\begin{tabular}{|c|c|c|c|c|c|c|}
\hline Model & OLS & OLS & SEM & SEM & LAG & LAG \\
\hline Distance-decay function & $\begin{array}{c}\exp (-0.10 \mathrm{dij}) \\
{[\text { Eq. 4.2] }}\end{array}$ & $\begin{array}{c}\text { 1/dis. } \\
\text { if } \mathrm{dij}<40 \mathrm{~km} \\
{[\mathrm{Eq} .4 .3]}\end{array}$ & $\begin{array}{c}\exp (-0.10 \mathrm{dij}) \\
{[\text { Eq. } 4.2]}\end{array}$ & $\begin{array}{c}\text { 1/dis. } \\
\text { if } \mathrm{dij}<40 \mathrm{~km} \\
{[\mathrm{Eq} .4 .3]}\end{array}$ & $\begin{array}{c}\exp (-0.10 \mathrm{dij}) \\
{[\text { Eq. 4.2] }}\end{array}$ & $\begin{array}{c}\text { 1/dis. } \\
\text { if } \mathrm{dij}<40 \mathrm{~km} \\
{[\mathrm{Eq} .4 .3]}\end{array}$ \\
\hline \multirow[t]{2}{*}{ Access_intra } & $0.0062 * * *$ & $0.0124 * * *$ & $0.0055 * * *$ & 0.0070 & $0.0025^{* *}$ & 0.0020 \\
\hline & $(0.0008)$ & $(0.0024)$ & $(0.0014)$ & $(0.0051)$ & $(0.0011)$ & $(0.0034)$ \\
\hline \multirow[t]{2}{*}{ Access_inter } & -0.0003 & 0.0043 & 0.0009 & 0.0130 & -0.0019 & -0.0034 \\
\hline & $(0.0017)$ & $(0.0046)$ & $(0.0032)$ & $(0.0100)$ & $(0.0024)$ & $(0.0066)$ \\
\hline \multirow{2}{*}{ Access_Bxl } & $0.0040 * * *$ & $0.0123 * * *$ & $0.0043 * * *$ & $0.0126^{* * *}$ & $0.0020 * * *$ & $0.0061 * * *$ \\
\hline & $(0.0006)$ & $(0.0019)$ & $(0.0009)$ & $(0.0031)$ & $(0.0006)$ & $(0.0020)$ \\
\hline \multirow[t]{2}{*}{ Jobs } & $0.0042 * * *$ & $0.0041 * * *$ & $0.0032 * *$ & 0.0018 & 0.0022 & 0.0018 \\
\hline & $(0.0014)$ & $(0.0014)$ & $(0.0015)$ & $(0.0016)$ & $(0.0017)$ & $(0.0016)$ \\
\hline \multirow[t]{2}{*}{ Popdens } & $0.0529 * *$ & 0.0244 & $0.0865^{*}$ & 0.0875 & $0.0817 *$ & $0.0979 *$ \\
\hline & $(0.024)$ & $(0.0318)$ & $(0.0483)$ & $(0.0631)$ & $(0.0464)$ & $(0.059)$ \\
\hline \multirow[t]{2}{*}{ Income } & $0.1126 * * *$ & $0.1123 * * *$ & $0.0994 * * *$ & $0.1099 * * *$ & $0.0631 * * *$ & $0.0659 * * *$ \\
\hline & $(0.0268)$ & $(0.0281)$ & $(0.0331)$ & $(0.0351)$ & $(0.0236)$ & $(0.0246)$ \\
\hline \multirow[t]{2}{*}{ Wallonia } & $-0.8182 * * *$ & $-0.8734 * * *$ & $-0.8523 * * *$ & $-0.9529 * * *$ & $-0.4724 * * *$ & $-0.4861 * * *$ \\
\hline & $(0.0688)$ & $(0.0708)$ & $(0.0841)$ & $(0.0955)$ & $(0.0745)$ & $(0.0737)$ \\
\hline \multirow[t]{2}{*}{ Coast } & $1.2169 * * *$ & $1.1732 * * *$ & $1.1207 * * *$ & $1.0455^{* * *}$ & $0.7525 * * *$ & $0.6717 * * *$ \\
\hline & $(0.1519)$ & $(0.1556)$ & $(0.2108)$ & $(0.2219)$ & $(0.1506)$ & $(0.1523)$ \\
\hline \multirow[t]{2}{*}{ Coastprox } & $0.6468 * * *$ & $0.6455 * * *$ & $0.5520 * * *$ & $0.5204 * * *$ & $0.2788 * *$ & $0.2385 * *$ \\
\hline & $(0.1898)$ & $(0.1937)$ & $(0.1618)$ & $(0.1652)$ & $(0.1136)$ & $(0.1114)$ \\
\hline \multirow[t]{2}{*}{ Slope } & $-0.0873 * * *$ & $-0.0894 * * *$ & $-0.0659 * * *$ & $-0.0653 * * *$ & $-0.0422 * * *$ & $-0.0409 * * *$ \\
\hline & $(0.0153)$ & $(0.0156)$ & $(0.0175)$ & $(0.0182)$ & $(0.0139)$ & $(0.0138)$ \\
\hline \multirow[t]{2}{*}{ Water } & 0.0006 & 0.0039 & 0.0134 & 0.0154 & -0.0030 & -0.0011 \\
\hline & $(0.0408)$ & $(0.0416)$ & $(0.0391)$ & $(0.0390)$ & $(0.0354)$ & $(0.0354)$ \\
\hline \multirow[t]{2}{*}{ Forests (ln) } & -0.0240 & $-0.0419 * *$ & -0.0160 & -0.0267 & -0.0136 & -0.0207 \\
\hline & $(0.0199)$ & $(0.0200)$ & $(0.0229)$ & $(0.0240)$ & $(0.0177)$ & $(0.0180)$ \\
\hline \multirow[t]{2}{*}{ Agriculture (ln) } & -0.0426 & $-0.1404 * * *$ & -0.0033 & -0.0531 & -0.0282 & -0.0594 \\
\hline & $(0.0548)$ & $(0.0542)$ & $(0.0723)$ & $(0.0811)$ & $(0.0629)$ & $(0.0685)$ \\
\hline \multirow[t]{2}{*}{ Constant } & $-5.5445^{* * *}$ & $-5.5458 * * *$ & $-5.2837 * * *$ & $-5.3814 * * *$ & $-2.9636 * * *$ & $-2.8611 * * *$ \\
\hline & $(0.5178)$ & (0.5389) & $(0.6409)$ & $(0.6674)$ & $(0.5113)$ & $(0.5119)$ \\
\hline \multirow[t]{2}{*}{$\lambda$} & & & $0.4809 * * *$ & $0.5114 * * *$ & & \\
\hline & & & $(0.0684)$ & $(0.0739)$ & & \\
\hline \multirow[t]{2}{*}{$\sigma$} & & & $0.4074 * * *$ & $0.4120 * * *$ & $0.4003 * * *$ & $0.4006^{* * *}$ \\
\hline & & & $(0.0165)$ & $(0.0172)$ & $(0.0164)$ & $(0.0166)$ \\
\hline \multirow[t]{2}{*}{$\rho$} & & & & & $0.4751 * * *$ & $0.5091 * * *$ \\
\hline & & & & & $(0.0518)$ & $(0.0491)$ \\
\hline \multicolumn{2}{|l|}{$\begin{array}{l}\text { Lagrange multiplier test } \\
(\lambda=0 \text { or } \rho=0)\end{array}$} & & $97.594 * * *$ & $99.194 * * *$ & $118.636 * * *$ & $135.319 * * *$ \\
\hline \multirow{2}{*}{$\begin{array}{l}\text { N } \\
\text { LogLikelihood }\end{array}$} & 588 & 588 & 588 & 588 & 588 & 588 \\
\hline & & & -320.59776 & -329.20275 & -309.9085 & -312.63358 \\
\hline Moran's I of residuals & $0.250 * * *$ & $0.252 * * *$ & $0.282 * * *$ & $0.306^{* * *}$ & $-0.037 *$ & $-0.050 * *$ \\
\hline (z stat.) & 9.997 & 10.079 & 11.280 & 12.219 & -1.391 & -1.918 \\
\hline
\end{tabular}

Table 3: OLS, SEM and LAG results for two specifications of the distance-decay function 


\begin{tabular}{|c|c|c|c|c|}
\hline Distance-decay function & $\begin{array}{l}\exp (-0.05 \mathrm{dij}) \\
\text { [Equation 4.1] }\end{array}$ & $\begin{array}{l}\exp (-0.10 \mathrm{dij}) \\
\text { [Equation } 4.2 \text { ] }\end{array}$ & $\begin{array}{c}1 / \text { dis. } \\
\text { if dij }<40 \mathrm{~km} \\
{[\text { Equation } 4.3]}\end{array}$ & $\begin{array}{c}\text { 1/dis. } \\
\text { if dij < 50km } \\
{[\text { Equation 4.4] }}\end{array}$ \\
\hline Access_intra & $\begin{array}{l}0.0011 * * \\
(0.0005)\end{array}$ & $\begin{array}{c}0.0025 * * \\
(0.0011)\end{array}$ & $\begin{array}{c}0.0020 \\
(0.0034)\end{array}$ & $\begin{array}{c}0.0008 \\
(0.0033)\end{array}$ \\
\hline Access_inter & $\begin{array}{l}-0.0001 \\
(0.0008)\end{array}$ & $\begin{array}{l}-0.0019 \\
(0.0024)\end{array}$ & $\begin{array}{l}-0.0034 \\
(0.0066)\end{array}$ & $\begin{array}{l}-0.0035 \\
(0.0054)\end{array}$ \\
\hline Access_Bxl & $\begin{array}{l}0.0009 * * \\
(0.0004)\end{array}$ & $\begin{array}{c}0.0020 * * * \\
(0.0006)\end{array}$ & $\begin{array}{c}0.0061 * * * \\
(0.0020)\end{array}$ & $\begin{array}{c}0.0060 * * * \\
(0.0021)\end{array}$ \\
\hline Jobs & $\begin{array}{c}0.0019 \\
(0.0015)\end{array}$ & $\begin{array}{c}0.0022 \\
(0.0017)\end{array}$ & $\begin{array}{c}0.0018 \\
(0.0016)\end{array}$ & $\begin{array}{c}0.0016 \\
(0.0014)\end{array}$ \\
\hline Popdens & $\begin{array}{l}0.0997 * * \\
(0.0423)\end{array}$ & $\begin{array}{l}0.0817^{*} \\
(0.0464)\end{array}$ & $\begin{array}{c}0.0979 * \\
(0.059)\end{array}$ & $\begin{array}{l}0.1121^{*} \\
(0.0588)\end{array}$ \\
\hline Income & $\begin{array}{c}0.0455^{*} \\
(0.0244)\end{array}$ & $\begin{array}{c}0.0631 * * * \\
(0.0236)\end{array}$ & $\begin{array}{c}0.0659 * * * \\
(0.0246)\end{array}$ & $\begin{array}{c}0.0688^{* * * *} \\
(0.0252)\end{array}$ \\
\hline Wallonia & $\begin{array}{l}-0.4705^{* * *} \\
(0.0760)\end{array}$ & $\begin{array}{c}-0.4724 * * * \\
(0.0745)\end{array}$ & $\begin{array}{c}-0.4861 * * * \\
(0.0737)\end{array}$ & $\begin{array}{c}-0.4830 * * * \\
(0.0744)\end{array}$ \\
\hline Coast & $\begin{array}{l}0.7673 * * * \\
(0.1540)\end{array}$ & $\begin{array}{c}0.7525 * * * \\
(0.1506)\end{array}$ & $\begin{array}{c}0.6717 * * * \\
(0.1523)\end{array}$ & $\begin{array}{c}0.6556 * * * \\
(0.1525)\end{array}$ \\
\hline Coastprox & $\begin{array}{l}0.3193 * * * \\
(0.1187)\end{array}$ & $\begin{array}{c}0.2788 * * \\
(0.1136)\end{array}$ & $\begin{array}{c}0.2385^{* *} \\
(0.1114)\end{array}$ & $\begin{array}{c}0.2321 * * \\
(0.1112)\end{array}$ \\
\hline Slope & $\begin{array}{l}-0.0350 * * \\
(0.0139)\end{array}$ & $\begin{array}{c}-0.0422 * * * \\
(0.0139)\end{array}$ & $\begin{array}{c}-0.0409 * * * \\
(0.0138)\end{array}$ & $\begin{array}{c}-0.0387 * * * \\
(0.0137)\end{array}$ \\
\hline Water & $\begin{array}{l}-0.0030 \\
(0.0355)\end{array}$ & $\begin{array}{l}-0.0030 \\
(0.0354)\end{array}$ & $\begin{array}{l}-0.0011 \\
(0.0354)\end{array}$ & $\begin{array}{l}-0.0036 \\
(0.0356)\end{array}$ \\
\hline Forests $(\ln )$ & $\begin{array}{c}-0.0154 \\
(0.0179)\end{array}$ & $\begin{array}{l}-0.0136 \\
(0.0177)\end{array}$ & $\begin{array}{l}-0.0207 \\
(0.0180)\end{array}$ & $\begin{array}{l}-0.0212 \\
(0.0180)\end{array}$ \\
\hline Agriculture (ln) & $\begin{array}{c}-0.0539 \\
(0.0621)\end{array}$ & $\begin{array}{l}-0.0282 \\
(0.0629)\end{array}$ & $\begin{array}{l}-0.0594 \\
(0.0685)\end{array}$ & $\begin{array}{l}-0.0579 \\
(0.0687)\end{array}$ \\
\hline Constant & $\begin{array}{l}-2.6977 * * * \\
(0.5059)\end{array}$ & $\begin{array}{c}-2.9636 * * * \\
(0.5113)\end{array}$ & $\begin{array}{c}-2.8611 * * * \\
(0.5119)\end{array}$ & $\begin{array}{c}-2.8767 * * * \\
(0.5144)\end{array}$ \\
\hline$\sigma$ & $\begin{array}{l}0.3999 * * * \\
(0.0163)\end{array}$ & $\begin{array}{c}0.4003 * * * \\
(0.0164)\end{array}$ & $\begin{array}{c}0.4006 * * * \\
(0.0166)\end{array}$ & $\begin{array}{c}0.4003 * * * \\
(0.0165)\end{array}$ \\
\hline$\rho$ & $\begin{array}{l}0.4834 * * * \\
(0.0512)\end{array}$ & $\begin{array}{c}0.4751 * * * \\
(0.0518)\end{array}$ & $\begin{array}{c}0.5091 * * * \\
(0.0491)\end{array}$ & $\begin{array}{c}0.5194 * * * \\
(0.0488)\end{array}$ \\
\hline $\begin{array}{l}\text { Lagrange multiplier test } \\
(\rho=0)\end{array}$ & $133.811 * * *$ & $118.636^{* * *}$ & $135.319 * * *$ & $146.093 * * *$ \\
\hline $\begin{array}{l}\text { N } \\
\text { Log Likelihood }\end{array}$ & $\begin{array}{c}588 \\
-309.77673\end{array}$ & $\begin{array}{c}588 \\
-309.9085\end{array}$ & $\begin{array}{c}588 \\
-312.63358\end{array}$ & $\begin{array}{c}588 \\
-312.93498\end{array}$ \\
\hline $\begin{array}{l}\text { Moran's I of residuals } \\
\text { (z stat.) }\end{array}$ & $\begin{array}{l}-0.038^{*} \\
-1.461 \\
\end{array}$ & $\begin{array}{c}-0.037 * \\
-1.391\end{array}$ & $\begin{array}{c}-0.050 * * \\
-1.918\end{array}$ & $\begin{array}{c}-0.055^{* *} \\
-2.112\end{array}$ \\
\hline
\end{tabular}

$* \mathrm{p}<0.1, * * \mathrm{p}<0.05, * * * \mathrm{p}<0.01$

Robust standard errors between parentheses.

Table 4: Results of the LAG model for four specifications of the distance-decay function 


\begin{tabular}{lc}
\hline Explanatory variables & $\begin{array}{c}\text { Effect on land prices in } \\
\text { s.d. }\end{array}$ \\
\hline Access_intra & 0.886 \\
Access_Bxl & 0.471 \\
Popdens & 0.957 \\
Income & 0.470 \\
Slope & -0.546 \\
Wallonia $^{*}$ & -0.161 \\
Coast $^{*}$ & 0.479 \\
Coastprox $^{*}$ & 0.137 \\
\hline
\end{tabular}

* Effects of dummy variables are calculated as variations in standard deviation units for $X=1$ with respect to $X=0$.

Table 5: Variations in land price in standard deviations for a one standard deviation change in the explained variable - LAG model with $f\left(d_{i j}\right)=\exp \left(-0.10 d_{i j}\right)$ 